\title{
Development of Interactive Learning Media Edugame Using ADDIE Model
}

\author{
Fadhli Ranuharja ${ }^{*}$, Genfri², Bayu Ramadhani Fajri ${ }^{3}$, Febri Prasetya ${ }^{4}$ Agariadne Dwinggo Samala $^{5}$ \\ 1,2,3,4,5Faculty of Engineering, Universitas Negeri Padang, Indonesia \\ *Corresponding Author: fadhliranu@ft.unp.ac.id
}

\begin{abstract}
INTISARI
Sejalan dengan program pembangunan Daerah Kab. Dharmasraya yaitu Program Dharmasraya Smart City dan implementasi Dharmasraya Smart Education. Penggunaan media inovatif seperti edugame belum tersentuh oleh pembelajaran di lingkungan sekolah dasar di dhamasraya. Dari hasil observasi dan wawancara dengan guru sekolah dasar SDN 08 Pulau Punjung di dhamasraya didapatkan hasil bahwa siswa lebih cepat memahami sesuatu dalam bentuk permainan. Oleh karna itu pembelajaran berbasis Edugame kepada guru Sekolah Dasar Dharmasraya tahun 2020 ini diharapkan akan menjadi salah satu ciri khas dunia pendidikan di Kab. Dharmasraya serta memberikan kontribusi yang positif dalam meningkatkan mutu pendidikan di tanah air. Tujuan dari penelitian ini adalah mengembangakan media pembelajaran berbentuk animasi Edu Game untuk pembelajaran di sekolah dasar. Metode penelitian yang dilakukan berupa pengembangan media pembelajaran menggunakan ADDIE. Dilakukan analisis kebutuhan khususnya dari siswa sebagai subjek dari penelitian ini, desain media pembelajaran menggunakan berbaiss edugame baik dari antarmuka hingga ke desain , kemudian diiemplementasikan ke dalam pengembangan media dan langkah akhir evaluasi dari media yang digunakan. Dari hasil uji validitas dari pakar media, edugame ini sudah dinilai valid, dari segi implementasi di lapangan penggunaan edugame ini mempermudah siswa SD 08 Pulau Punjung untuk memahami materi.
\end{abstract}

Kata kunci: Media Pembelajaran; Edu-Game; Inovasi Pembelajaran; ADDIE

\begin{abstract}
In line with the district development program. Dharmasraya, namely the Dharmasraya Smart City Program and the implementation of Dharmasraya Smart Education. The use of innovative media such as edugame has not been touched by learning in the elementary school environment at Dhamasraya. From the results of observations and interviews with elementary school teachers at SDN 08 Pulau Punjung in dhamasraya, it was found that students understood things more quickly in the form of games. Therefore, Edugame-based learning for Dharmasraya Elementary School teachers in 2020 is expected to become one of the characteristics of the world of education in Kab. Dharmasraya and make a positive contribution in improving the quality of education in the country. The purpose of this research is to develop learning media in the form of Edu Game animation for learning in elementary schools. The research method used is the development of learning media using ADDIE. An analysis of the needs, especially of students as the subject of this research, was carried out. The design of instructional media used a variety of edugame from the interface to the design, then implemented it into media development and the final step was evaluation of the media used. From the results of the validity test from media experts, this edugame has been considered valid, in terms of implementation in the field, the use of this edugame makes it easier for students of SD 08 Pulau Punjung to understand the material.
\end{abstract}

Keywords: Learning Media; Edu-Game; Learning Innovation; ADDIE.

\section{INTRODUCTION}

As stated in Article 41 paragraph (3) concerning the National Education System, it mandates that the central and regional governments must facilitate education units with educators and educational personnel necessaries to ensure the ideal conduct of a high quality education. The high qualified education is the one that serves to prepare students to face the challenges of change in local, national, and global life through active, innovative, creative, and fun learning. Therefore, education needs to be developed sustainably in 
accordance with the innovations of science, technology, and arts.

Teachers as a part of the national education system have a strategic role in preparing students to create a smart, skilled, and righteous future generation of Indonesia. In addition, the main duties of teachers according to Government Regulation Number 74 of 2008 concerning Teachers of Article 52 paragraph (2) include planning the learning process, conducting the learning process, assessing learning outcomes, guiding and training students, and carrying out additional tasks.

To carry out their duties professionally, a teacher should not only possess the technical educational abilities, but also a reliable personality so that the teacher can become a great role model for students, family and society. In line with development policies that place human resource development (HR) as a national development priority, the position and role of teachers are rising to be more strategic in preparing the quality of human resources in facing the globalisation era.

As a matter of fact, the professional teachers possess four categories of competencies such as professional, pedagogical, personal and social competences. For professional competence, a teacher is required to master the competence according to the level of education of students. On the pedagogical competence, a teacher should be capable to conduct a creative, innovative, interesting and fun learning in order to achieve the competencies or indicators that have been formulated. Additionally, for the personality competence, a teacher must possess the characters that can be a role model for students. In social competence, a teacher must acquire a good communication skill with the students, fellow teachers, education staff, parents, and the community.

The learning process in education institution is one of the most important parts of education at all levels which requires a continual improvement. [1]. during the learning process, students must gain a learning experience to solve the problems faced. This is important for all parties, especially teachers, in an effort to form "the smart and highly competitive Indonesians" in facing the global competition in which teachers and students are required to be literate in science and technology, especially information technology [2]. In line with this, teachers must carry out various types of professional development activities, including innovative learning. To achieve the expected learning process, each teacher is required to possess the four competencies as stated before.

One of the efforts to increase the motivation, dedication, loyalty, and professionalism of the teachers is to innovate the development of Edugame learning media for the teachers in Elementary School 1 Dharmasraya Regency. This activity is aimed at developing the learning media in science subjects to improve the quality of education in Dharmasraya regency, so this effort is expected to gradually improve the teacher's performance and students' achievement in a positive manner.

\section{A. Game}

Greg [5] defines game as an art where the player can use all the resources and facilities in the game to achieve the goal of the game.

\section{B. Edugame}

The combination of learning and playing is an element of Edugame which allows the students who make use of it to attain the element of education and feel a sense of joy because of the attractive form of Edugame, [6]. In line with [7] educational games are the interactive media which aids the students to learn and are more eager to explore further.[8]

\section{Learning Media}

The use of media in learning process can generate new aspiration and interest, increase the motivation and stimulation of learning activities, and even have a psychological impacts on the students [8] some benefits of media in which the student can gain during the learning process are (i) the media can foster the students' learning motivation since the attractive teaching method will be able to attract their attention; (ii) the interpretation of teaching materials will become much more obvious so that it can be comprehended by the students and it will result on the mastery and achievement of teaching objectives [9]; (iii) teaching methods will be more varied, not based solely on verbal communication through words; and (iv) students can do more activities during learning activities, not only listening but also observing, demonstrating, practicing, and acting [8].

\section{METHOD}

To obtain accurate information about the process and results of this research, the Analysis-DesignDevelopment-Implementation-Evaluation (ADDIE) 
method is used for data collection. Addie method techniques used in this research include:

1. Data Collection analysis

a. Observation

Direct observation is carried out in the field by observing the teaching and learning process at SMKN 1 Dharmasraya thus the entire process that is running and the needs of students and teachers in the learning process can be spotted.

b. Interview

Direct observation is carried out in the field by observing the teaching and learning process at SMKN 1 Dharmasraya thus the entire process that is running and the needs of students and teachers in the learning process can be spotted.

c. Reference of Study

Reference studies are carried out so that the data obtained is more accurate and reliable. This study was obtained by collecting various related journals, books both in the form of e-books and hardcopy of books.

2. Software Development Methods

Based on the issues previously described, this study will produce a learning media product. According to Sugiyono [9] research and development methods are the methods used to produce a particular product and test the effectiveness of the product. In fact, this research procedure adapts the ADDIE development model consists of five stages which include analysis, design, and evaluation (Sugiyono, 2015).

The ADDIE model consists of 5 components that are interrelated and structured systematically, which means that from the first stage to the fifth stage in its application, it must be systematic and cannot be ordered randomly. These five steps are very simple compared to other design models. Because of its simplicity and systematically structured, this design model is easy to be comprehended and applied [14]. The ADDIE development research steps in this study are presented in the form of the chart below:

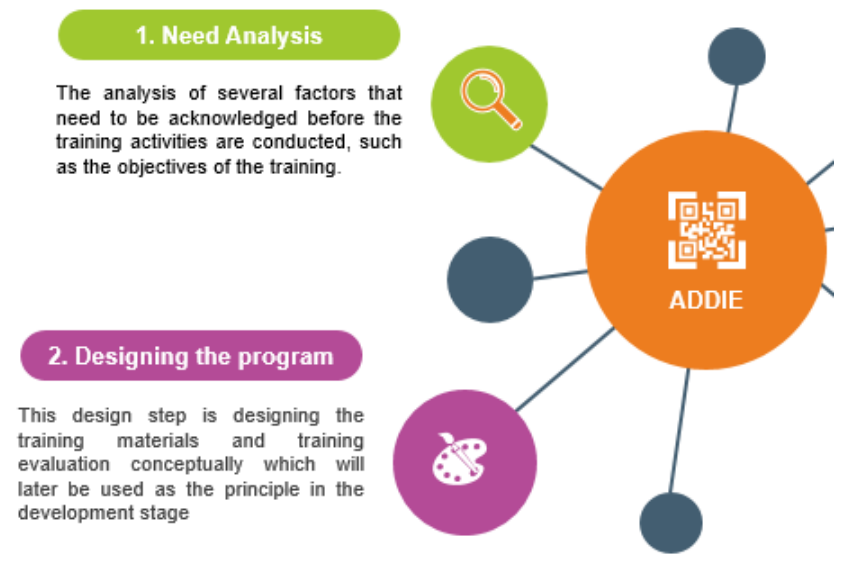

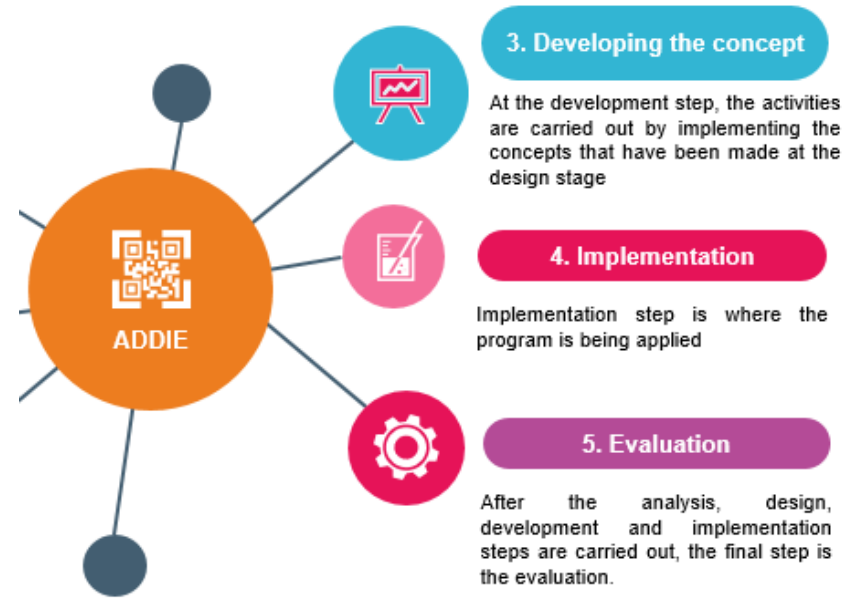

Fig. 1 Addie model diagram model

Here are the steps of the ADDIE development

a. Analysis

The first stage is to analyse the characteristics of students, the needs of the materials that will be used in the edugame applications and the needs of the tools or devices used. The primary data is obtained through interviews and secondary data from the existing research references.

b. Design

Creating pages on the app starts from the front page of the main menu which is accessible and the page/layout will start the game. Final score page in which the entire pages are sorted one by one.

\section{c. Development}

This step is where the interactive animation media, media validation and media revision are being created. The development is started with the media validation and application content.

\section{d. Implementation}

The implementation of the edugame application is implemented at SDN 08 PULAU PUNJUNG Dharmasraya. As a matter of fact, one class consists of 25 students and 1 teacher in which the teacher uses their own computer to guide students in using the edugame app.

\section{e. Evaluation}

The evaluation is carried out after the program is implemented then the shortcomings will 
be analysed and improved. Hence, the resulting product is more advantageous and practical to use

\section{A. Analysis}

\section{Software analysis}

The interactive edugame implemented in Science learning was aimed for the early childhood who has just admitted into the learning period while playing. In addition, the primary data obtained from the interviews at the primary schools of Dharmasraya regency explained the needs of edugame application users which consist of the students and teachers of SDN 08 Pulau Punjung. As a matter of fact, the learning materials used in the implementation of the game was the identification of various types of hazardous and harmless substances to the human body. In designing the interactive animation, supporting equipment was also needed in the process of creating and testing interactive animation learning so it would be effective. The aspects needed to create interactive animation learning were:

Table 1. Software Requirements

\begin{tabular}{ll}
\multicolumn{1}{c}{ Requirements } & \multicolumn{1}{c}{ Note } \\
\hline Windows 10 & Operation system \\
\hline Adobe Photoshop CS6 & Image editor support app \\
\hline Construct 2 & $\begin{array}{l}\text { Editor designed the edugame } \\
\text { application }\end{array}$ \\
\hline \multicolumn{2}{c}{ Table 1. Hardware Requirements } \\
\hline \multicolumn{1}{c}{ Requirements } & Note \\
\hline Pentium 4 2.0 GHz & Prosessor \\
\hline 4 Gigabytes RAM & RAM Memory \\
\hline Seagate 500 Gb & Hardisk Capacity \\
\hline
\end{tabular}

\section{B. Design}

Interface design was performed by observing the users who use the application with the purpose that the users could easily use the buttons and features in the edugame. Additionally, interface design provided information to the user so that it would be in line with the objectives aimed to be achieved. Edugame interface design starts from:

a) Design interface layout 1 edugame healthy lifestyle

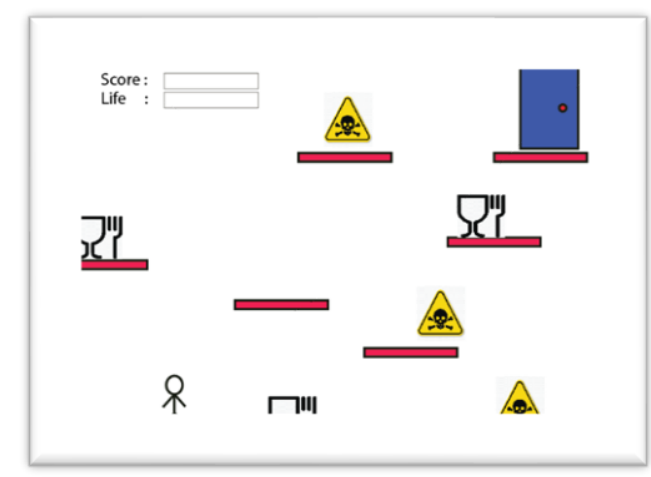

Fig. 2 Designing layout for edugame

a) Design interface layout 1 edugame healthy lifestyle

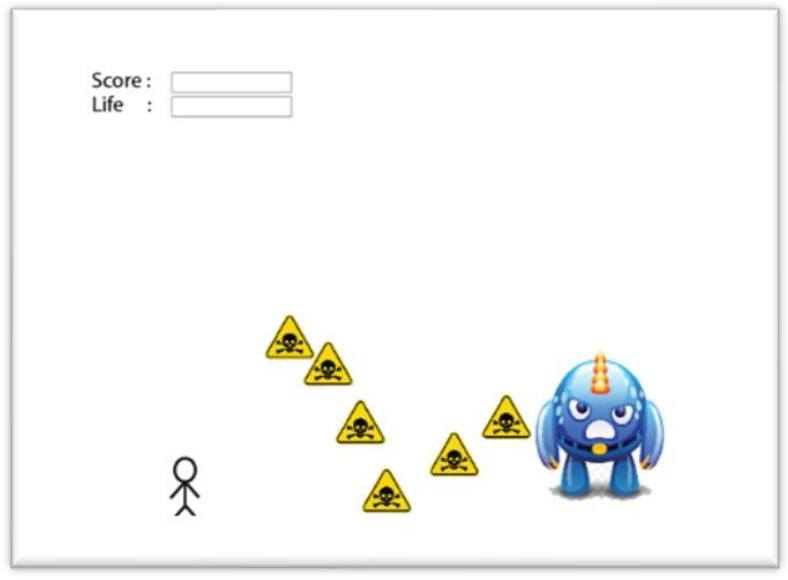

Fig. 3 Designing last stage layout

b) Edugame rules design

The player was given 5 lives at the beginning of the game. The goal of the game was to collect as many points as possible by getting healthy items. Furthermore, when the player collided with an item that did not make the body healthy, the player's life would be reduced by minus one. At the end of the stage, the player must defeat the marijuana boss to win the game in which the marijuana boss will pull out a deadly weapon for every few seconds.

\section{Development}

Explaining the development of the interface contained in the edugame application applied to edugame developer applications by using Construct 2 . In fact, the app built a simple game themed a user friendly 2D animations. This construct used JavaScript programming language to build the function buttons or design the rules of the game. 


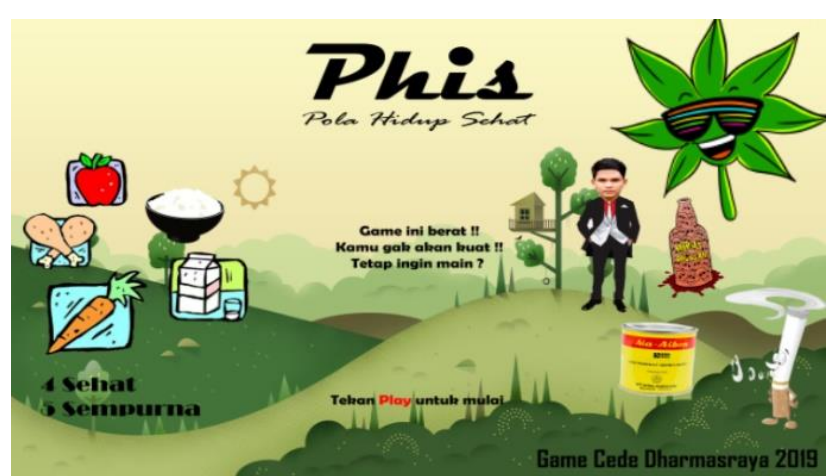

Fig. 4 User interface in main page edugame

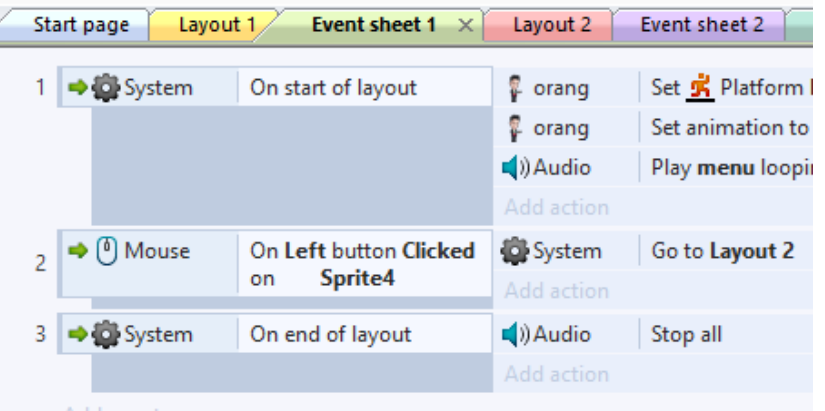

Fig. 5 Layout and event sheet

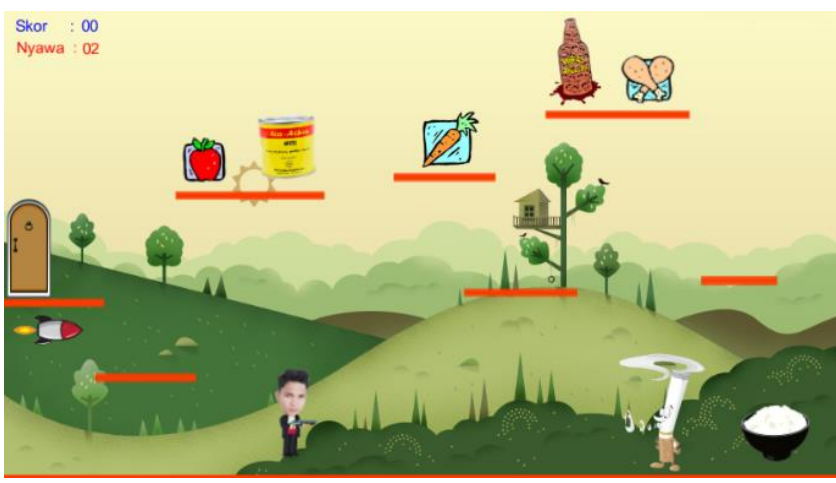

Fig. 6 edugame user interface for gameplay

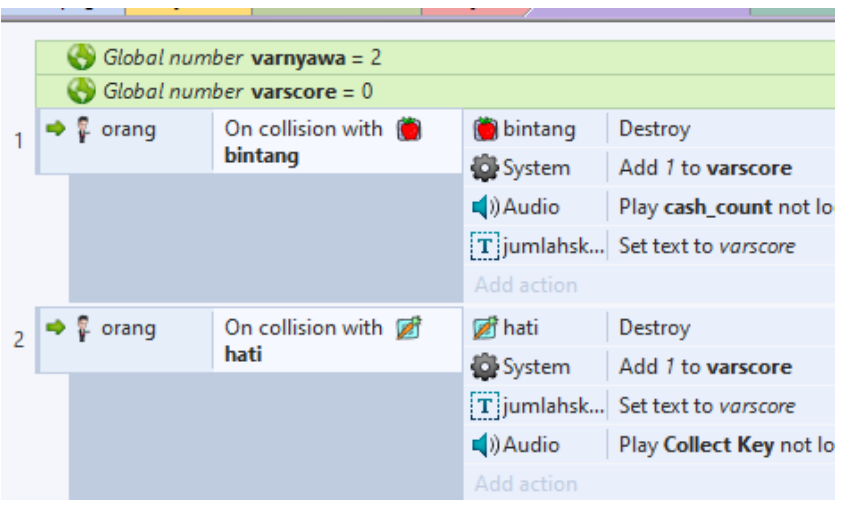

Fig. 7 Evensheet and object behavior

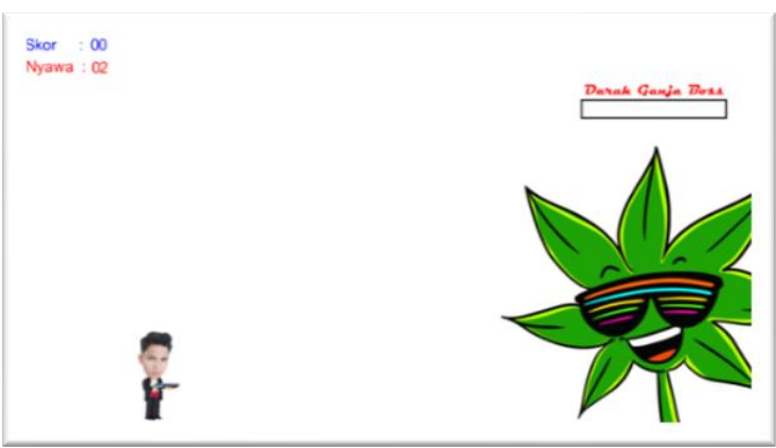

Fig. 8 Figting boss in edugame

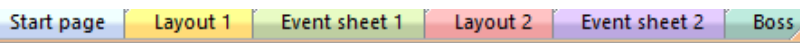

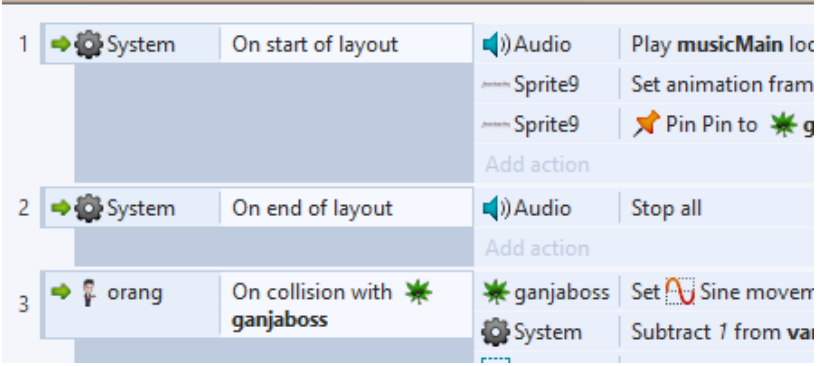

Fig. 9 Event sheet boss layout

\section{Implementation}

\section{1) Hardware specification}

- Netbook /PC tower

- Minimum AMD Ryzen 3 or Intel Dual Core CPU

- 320 GB storage

- 2 GB RAM

- Mouse

- Keyboard

2) Software specifications

- Windows 7 or the latest windows version

- Macromedia

- Adobe Photoshop

- Adobe Illustrator CS

3) The Edugame Application Testing in the Class

The test was conducted in a labor computer consisted of 20 students and 1 Subject teacher.

\section{E. Evaluation}

The trial was conducted in a small classroom with 25 students and 1 teacher in science subjects on the interactive animation learning applications that had been created and it was subsequently tested through software testing technique such as white box testing and black box testing. Furthermore, testing was performed to ensure that the whole statements on the program had been 
executed at least once during the testing process and undoubtedly, the entire logical conditions had been tested.

1) Whitebox Testing

By using the Whitebox testing method, the following test cases were obtained (Pressman, 2010):

a) Ensured that all independent paths in a module had been executed at least once.

b) Made all logical decisions on the right and wrong sides.

c) Carried out all loops within their limits and operational limits.

d) Performed internal data structures to ensure validity.

Last, the White Box testing method operated a procedural design control structure (structural testing) to obtain a test case. Furthermore, the test was carried out to ensure that all statements in the program have been executed at least once during the test and that all logical conditions had been tested.

Measuring cyclomatic complexity (a quantitative measure of the logical complexity of a program) could be obtained by calculations such as $V(G)=E$ $-\mathrm{N}+2$ where $\mathrm{E}=$ the number of edges of the flow graph indicated by arrows, and $\mathrm{N}=$ the number of flow graph nodes denoted by circle image.

\section{RESULTS AND DISCUSSION}

Describe the results in a clear and logical order. Narration contains information that is extracted from the data, not duplicated with text.

\section{CONCLUSION}

After conducting edugame-based learning media training in the Education Bureau of Dharmasraya regency, it can be concluded:

1. Based on the implementation and evaluation of edugame program through edugame-based learning media presentations in general, the knowledge and mastery of teachers at the Elementary School in Dharmasraya regency about the innovation of learning process in the classroom using Edugame media has gradually improved.

2. The attitude, understanding and motivation of teachers at SDN 08 PULAU PUNJUNG as the trainees to produce edugame-based learning media work have been increasing significantly.

The skill of using Edugame media as a platform to deliver teaching materials to students is well acquired by the teachers as their insights on Edugame increase.

\section{REFERENCES}

[1] A. D. Samala, B. R. Fajri, F. Ranuharja, and R. Darni, "Pembelajaran Blended Learning Bagi Generasi Z," J. Teknol. Inf. dan Pendidik., 2020.

[2] F. Ranuharja, B. R. Fajri, and A. D. Samala, "Sistem Pelayanan Bantuan Mentor Bimbingan Belajar (Bambimbel) Berbasis Web," J. Teknol. Inf. dan Pendidik., 2020.

[3] Y. Kwartolo, "Teknologi Informasi dan Komunikasi dalam proses Pembelajaran," J. Pendidik. Penabur, 2010.

[4] B. R. Fajri, A. D. Samala, and F. Ranuharja, "Perancangan Media Interaktif Gerak Tari Topeng Patih pada Wayang Topeng Malangan Menggunakan Sensor Kinect," INVOTEKJ. Inov. Vokasional dan Teknol., 2020.

[5] G. Costikyan, "Games, Storytelling and Breaking the String," in Second Person: Roleplaying and Story in Playable Media, 2007.

[6] A. Hartanto, R. Timothy, and Yoannita, "Android Sebagai Media Pembelajaran Siswa Sekolah Dasar," STMIK GI MDP, 2013.

[7] Bayu Ramadhani Fajri, "Interactive Media Introduction To Motion Dance And Visual Meaning Of Topeng Malangan," in international conference on new media 2015, 2015, pp. 258262.

[8] I. Falahudin, "Pemanfaatan Media dalam Pembelajaran," Lingk. Widyawiswara, 2014.

[9] Ramansyah, Wanda. "Pengembangan education game (EDUGAME) berbasis android pada mata pelajaran bahasa inggris untuk peserta didik sekolah dasar." Jurnal Ilmiah Edutic 2.1 (2015): 1-9.

[10] Aini, Baiq Olatul, Khaerunnisa Cantika Ayu, and Siswati Siswati. "Pengembangan Game Puzzle Sebagai Edugame Berbasis Android Untuk Meningkatkan Kemampuan Berpikir Matematika Siswa SD." JTAM (Jurnal Teori dan Aplikasi Matematika) 3.1 (2019): 74-79.

[11] "Pembangunan dan Penilaian Bahan Pengajaran dan Pembelajaran Berasaskan Web - Webquest bagi Mata Pelajaran ICT (Development and Evaluation of Webquest for Information and Communication Technology 
Subject)," J. Pendidik. Malaysia, 2009.

[12] G. Ganefri, B. R. Fajri, F. Ranuharja, F. Prasetya, R. Fadillah, and F. Firdaus, "Mini Server Lentera Sebagai Alternatif Pembelajaran Digital Di Daerah 3t," J. Teknol. Inf. dan Pendidik., 2019.

[13] Sugiyono, Metode Penelitian Pendidikan Pendekatan Kuantitaif, Kualitatif, dan R\&DSugiyono. 2013. "Metode Penelitian Pendidikan Pendekatan Kuantitaif, Kualitatif, dan R\&D." Metode Penelitian Pendidikan Pendekatan Kuantitaif, Kualitatif, dan R\&D. https://doi.org/10.1. 2013.

[14] F. Ranuharja, Oktoria, and N. Dwiyani, "Perancangan Sistem Informasi Jasa Penjualan Barang Berbasis Web Untuk Civitas Akademika Perguruan Tinggi di Kota Padang," J. Vocat. Tek. Elektron. dan Inform., 2014.

[15] A. D. Samala, B. R. Fajri, and F. Ranuharja, "Desain Dan Implementasi Media Pembelajaran Berbasis Mobile Learning Menggunakan Moodle Mobile App," J. Teknol. Inf. dan Pendidik., vol. 12, no. 2, pp. 13-19, Dec. 2019, doi: 10.24036/tip.v12i2.221. 
